\title{
GEJALA DEPRESI TOKOH UTAMA DALAM NOVEL REPRESI KARYA FAKHRISNA AMALIA
}

\author{
Siti Maemunah \\ Universitas Pamulang, Jakarta, Indonesia \\ dosen02349@unpam.ac.id
}

\begin{abstract}
Symptoms of Depression in the Main Character in Fakhrisna Amalia's Refresi Novel. According to Aaron Beck, the problem in this study is more focused on the main character's depressive symptoms, who analyzes his depressive symptoms through 4 depressive symptoms. The method used in this research is qualitative. The reason for using this method is that the data presentation and data analysis in this study are presented in sentences and descriptions. The data used in this study are excerpts from dialogues from primary data sources, namely the novel Represi by Fakhrisna Amalia. The secondary data sources are obtained from reference books or documents related to the research object by reading, studying, and understanding. The data collection technique used is to collect data using reading and note-taking techniques. Read the entire contents of the novel carefully, mark the essential things in the novel, describe all the data that has been obtained from the data. In collecting the data, the form of sentences containing the psychological aspects of the main character in the novel Refresi by Fakhrisna Amalia, which is described. Based on the research results conducted in the novel Represi by Fakhrisna Amalia, there are symptoms of depression experienced by the main character: emotional, cognitive, motivational, and physical symptoms.
\end{abstract}

Keywords: symptoms of depression, main character, novel

\begin{abstract}
ABSTRAK
Gejala Depresi pada tokoh utama dalam Novel Represi Karya Fakhrisna Amalia.Penelitian bertujuan untuk mengemukakan gejala depresi tokoh utama novel Represi Karya Fakhrisna Amalia. Masalah dalam Penelitian ini lebih terfokus kepada gejala depresi tokoh utama, yang menganalisis gejala depresinya melalui 4 gejala-gejala depresi menurut Aaron Beck. Metode yang digunakan dalam penelitian ini adalah kualitatif alasan menggunakan metode ini, karena penyajian data maupun analisis data pada penelitian ini disampaikan dalam bentuk kalimat dan uraian. Data pada penelitian ini yang digunakan adalah berupa kutipan-kutipan dari dialog yang berasal dari sumber data primer, yaitu novel Represi Karya Fakhrisna Amalia. Adapun Sumber data sekunder diperoleh dari buku-buku refrensi atau dokumen yang berkaitan dengan objek penelitian dengan cara membaca, mempelajari dan memahami. Teknik pengumpulan data yang digunakan adalah mengumpulkan data menggunakan teknik baca dan catat. Membaca cermat keseluruhan isi novel tersebut, menandai hal yang penting dalam novel, mendeskripsikan semua data-data yang sudah diperoleh dari data tersebut. mengumpulkan data berupa kalimat yang mengandung kondisi aspek psikologi tokoh utama dalam novel Represi Karya Fakhrisna Amalia, yang diuraikan. Berdasarkan hasil penelitian yang dilakukakn, dalam novel Represi karya Fakhrisna Amalia terdapat gejala depresi yang dialami tokoh utama, yakni gejala-gejala emosional, gejala-gejala kognitif, gejala-gejala motivisional dan gejala-gejala fisik.
\end{abstract}

Kata kunci : gejala depresi, tokoh utama, novel

Gejala Depresi Tokoh Utama dalam Novel Represi Karya Fakhrisna Amalia 


\section{PENDAHULUAN}

Pada zaman modern ini, banyak manusia yang mengalami stres, kecemasan, dan kegelisahan. Depresi yang dibiarkan berlarut membebani pikiran dan dapat menganggu sistem kekebalan tubuh. Apabila berada dalam rasa emosi yang negatif seperti rasa sedih, benci, iri, putus asa,kecemasan dan kurang bersyukur maka sistem kekebalan tubuh akan menjadi lemah.

Gangguan depresi pada umumnya dicetuskan oleh peristiwa hidup tertentu. Kenyataanya peristiwa hidup tersebut tidak selalu diikuti oleh depresi, hal ini mungkin disebabkan karena adanya faktor-faktor lain yang ikut berperan mengubah atau memengaruhi hubungan tersebut. Jarang terjadi faktor depresi disebabkan oleh satu faktor saja, tetapi lebih sering disebabkan oleh berbagai faktor yang berinteraksi dalam berbeagai kombinasi sehingga menciptakan suatu kondisi tertentu yang berpengaruh terhadap tinggi rendahnya tingkat dan fruekensi depresi.

Depresi dipahami sebagai gangguan yang tidak disadari baik oleh penderita maupun orang-orang di sekitarnya. Menurut Pradana (2016) depresi disebut juga sebagai gangguan yang tak terlihat (invisible disease). Berbeda dengan gangguan lain seperti flue di mana penderita sadar bahwa ia terkena flue, sedangkan penderita depresi tidak sadar bahwa dirianya mengalami depresi. Bahkan banyak orang yang menganggap gangguan depresi adalah masalah yang berkaitan dengan keimanan seseorang saja dan tidak dianggap sebagai gangguan psikologis yang memerlukan pertolongan profesional dalam bidang terssebut. Faktor ini menyebabkan terjadinya $80 \%$ dari penderita depresi tidak mendapatkan penanganan yang semestinya.

Gejala depresi merupakan gejala perilaku dan perasaan yang secara spesifik dapat dikelompokan sebagai depresi. Perlu diketahui bahwa setiap orang mempunyai perbedaan yang mendasar yang kemungkinan suatu peristiwa atau perilaku dihadapi secara berbeda dan memunculkan reaksi yang berbeda antara satu orang dengan yang lainnya (Lumangga, 2009).

Depresi dipahami sebagai suatu gangguan di bawah alam sadar atau perasaan yang ditandai dengan rasa sedih terus-menerus sehingga dapat membuat kondisi fisik dan kehidupan sosialnya terganggu (Pieter dan Namora: 2012). Asia Tenggara menjadi wilayah tertinggi terjadinya depresi hingga menyentuh $86,94(27 \%)$ dari 322 miliar individu. Menurut WHO, di tahun 2017 Indonesia berada di urutan kelima dengan jumlah penderita depresi sebesar (3,7\%). Berdasarkan hasil RISKESDA 2018, penderita depresi di Indonesia terjadi pada umur $\geq 15$ tahun. Hal ini menunjukkan bahwa $(6,1 \%)$ remaja Indonesia mengalami depresi. Adapun penderita depresi lebih tinggi terjadi di provinsi Sulawesi Tengah dengan presentase $(12,3 \%)$ (Kemenkes, 2018).

Gejala-gejala depresi yang terjadi pada remaja ditandai dengan perasaan mudah tersinggung, takut, tidak bersemangat, tertelan, sedih, konflik dengan teman, dan konflik dengan keluarga (Rahmayanti \& Rahmawati, 2018). Perilaku remaja yang mengalami depresi juga mengalami perubahan, misalnya sebelum mengalami depresi remaja itu senang bermain dengan teman-temannya namun setelah mengalami depresi, remaja itu lebih suka menyendiri dan tidak dapat bersosialisasi dengan lingkungan (Haryanto, Hartati dan Siti 2015). Oleh karenanya, orang tua harus lebih memperhatikan perubahan-perubahan yang terjadi pada anak-anaknya, khususnya ketika memasuki masa remaja, karena apabila depresi ini tidak ditangani dengan tepat dan justru berkelanjutan akan menimbulkan pemikiranpemikiran negatif seperti pemikiran untuk melakukan bunuh diri.

Menurut Davison (dalam Pramana dan Puspitadei, 2014) faktor-faktor yang mempengaruhi adanya pemikiran untuk melakukan bunuh diri adalah kehilangan cinta, pengaruh lingkungan, perasaan tidak berdaya, masalah akademis, dan masalah keluarga seperti perceraian atau meninggal. Berdasarkan hasil Survei Kesehatan Global berbasis sekolah pada tahun 2015 setidaknya terdapat 18,6\% remaja di DKI Jakarta mempunyai keinginan bunuh diri, dan remaja yang mengalami gangguan emosional sebesar $35 \%$ memiliki keinginan untuk melakukan bunuh diri, sedangkan 145 remaja normal mempunyai ide bunuh diri. 
Dalam karya sastra sering kali menggambarkan emosi-emosi yang berasal dari tokohnya. Emosi manusia memiliki kesinambungan dengan masalah psikologi atau kejiwaan. Sehingga kita dapat memahami kejiwaan seseorang melalui sastra. Karya sastra bisa dikaji menggunakan psikologi sastra karena sastra menampilkan karakter tokoh yang berhubungan dengan masalah psikologis. Menurut Yanti (2015) karya sastra dipahami sebagai hasil karya manusia dengan mendayungkan imajinasi yang terdapat dalam pengarangnya. Keberadaan karya sastra dalam kehidupan manusia dapat mengisi kehausan jiwa karena membaca karya sastra bukan hanya memberikan hiburan, tetapi dapat memberikan pencerahan jiwa. Psikologi sastra adalah telaah karya sastra yang diyakini mencerminkan proses dan aktivitas kejiwaan (Minderop, 2013).

Dalam Novel Represi Karya Fakhrisina Amalia terdapat gejala psikologis yang dialami oleh tokoh utama. Tokoh utama dalam novel ini menceritakan kehidupan seorang Anna pasca percobaan bunuh diri yang dilakukakan karena mengalami gejala-gejala depresi. Tokoh utama ini banyak sekali mengalami permasalahan dalam hidupnya, Permasalahan dengan orangtua, Anna harus selalu mengikuti apa yang orang tuanya inginkan sehingga Anna tidak bisa memutuskan keinginanya sendiri, Permasalahan percintaan nya dengan Sky, Anna ditinggal oleh Sky dan itu membuat hidup Anna menjadi seperti Depresi Anna pernah melakukan bunuh diri karena ia merasa hidupnya sudah tak berguna Anna menjauhkan sahabatnya karena Sky melarang Anna berteman lagi dengan sahabatnya. Anna juga mempunyai Masa lalu yang kelam ketika ia di lecehkan oleh anak tetangganya sendiri, yaitu Mas Bayu, tetapi Anna memendam semua permasalahanya sendiri, hingga timbulah gejala-gejala depresi pada diri Anna.

Penelitian ini juga memiliki penelitian serupa dengan penelitian terdahulu, yaitu penelitian yang dilakukan Diana (2014) dengan judul penelitian "Gejala Depresi dalam film Tristan et iseut" Tinjauan Psikoanalitis. Penelitian ini bertujuan untuk mengetahui gejala depresi yang ditunjukan melalui perilaku tokoh Tristan dalam Film Tristan et Iseut hasil dari penelitian ini mengalami semua gejala depresi yang di kemukakan oleh Beck, namun bentuk menifestasi yang menonjol adalah menifestasi emosi karena dalam film ini Tristan lebih menunjukkan emosi seperti marah, sedih, cemburu dan menangis.

Khotimah (2019) juga melakukan penelitian serupa dengan judul penelitian "Depresi Tokoh Mu dan Shu Yawang dalam Film Sweet Sixteen Sutradara Jo Jin-Kyu (Kajian Psikologi Sastra). Tujuan penelitian ini mendeskripsikan gejala depresi dan faktor penyebab depresi pada tokoh utama. Hasil penelitian ini gejala depresi yang dialami tokoh $\mathrm{Xia} \mathrm{Mu}$ yang menonjol adalah marah sedangkan gejala depresi yang dialami oleh tokoh Shu Yawang seimbang,Faktor penyebab depresi tokoh $\mathrm{Xia} \mathrm{Mu}$ yaitu kehilangan orang tua, hubungan cinta tidak harmonis, adapun menyesali yang sudah terlewat. Adapun faktor yang dialami Shu Yawang yakni mencemaskan orang-orang yang dicintai dan menyesali hal-hal yang sudah terlewat.

Luh (2017) melakukan penelitian serupa dengan judul penelitian " Gejala dan jenis depresi pada tokoh Yves dalam film Yves Saint Laurent: Kajian Pskologi Abnormal. Peneltian ini bertujuan untuk menggambarkan gejala depresi pada tokoh Yves beserta jenis depresi yang dialaminya. Teori yang digunakan adalah Teori Aaron Beck. Hasil dari penelitian ini adalah Yves mengalami semua gejala depresi yang dikemukakan oleh Aaron Beck yaitu gejala emosional, gejala kognitif, gejala motivisional dan gejala fisik. Jenis depresi yang dialami tokoh Yves termasuk depresi berat karena ia menunjukkan tujuh gejala episode mayor menurut APA yaitu suasana hati depresi, kehilangan rasa senang atau minat aktivitas sehari-hari, tidak dapat mengemukakan kegembiraan saat menemukan hal yang menyenangkan, gangguan slera makan, reterdasi psikomotor, kehilangan energi, merasa tidak berharga dan merasa berdosa, dan susah untuk berpikir. Yang membedakan peneliti penulis dengan peneliti-peneliti lainnya, objek yang digunakan peneliti adalah novel sedangkan peneliti lain menggunakan Film. Peneliti lain meneliti novel tetapi menggunakan teori yang berbeda. Maka dari itu penulis penelitian ini 
memiliki unsur kebaruan.

\section{METODE PENELITIAN}

Penelitian ini menggunakan metode penelitian kualitatif dengan menekankan pencarian makna dan konsep maupun deskripsi mengenai fenomena dengan disajikan secara naratif dengan tujuan menemukan jawaban terhadap suatu pertanyaan secara sistematis (Winarni, 2018).

Penelitian kualitatif dipahami sebagai penelitian yang bermaksud untuk memahami fenomena tentang apa yang dialami oleh subjek penelitian". Data penelitian kualitatif tidak menggunakan analisis statistik, tapi lebih banyak menggunakan analisis naratif. Deskripsi yang mendetail tentang situasi, kegiatan, pristiwa maupun fonomena yang menyangkut manusianya maupun berbagai interkasinya dan deskripsi yang mendetail tentang sikap dan tingkah laku seseorang. Pernyataan tersebut sejalan dengan pendapat (Moleong, 2016; Suriadiman \& Anita, 2021; (Alber, 2017; (Alber \& Rahayu, 2017; dan Winarni, 2018).

Ratna (2010) mengungkapkan bahwa metode penelitian kualitatif adalah penafsiran dengan menyajikannya dalam bentuk deskripsi, kualitas penafsiran dalam metode ini dengan dibatasi oleh hakikat fakta-fakta social, artinya fakta sosial adalah fakta sebagaimana ditafsirkan oleh subjek. Data pada penelitian ini adalah berupa kutipan-kutipan dari dialog yang berasal dari sumber data primer, yaitu novel Represi Karya Fakhrisna Amalia yang diterbitkan oleh Gramedia Pustaka Utama pada tahun 2018 dengan tebal 257 halaman (Amalia, 2018). Adapun Sumber data sekunder diperoleh dari buku-buku refrensi atau dokumen yang berkaitan dengan objek penelitian dengan cara membaca, mempelajari dan memahami.

Teknik pengumpulan data dengan cara membaca, menandai, mendeskripsikan semua data yang sudah diperoleh, mengumpulkan data berupa kalimat yang berkaitan dengan penelitian dan data penyajian berupa uraian yang merupakan hasil penelitian secara menyeluruh serta membuat keseimpulan. Sedangkan teknik analisis data dengan Reduksi Data (merangkum memilih hal-hal pokok, memfokuskan hal penting dan mencari yang perlukan bertujuan pada penemuan). Penyajian Data (bentuk uraian singkat berupa kalimat atau naratif).Penarik Kesimpulan dan verifikasi (keseimpulan yang dikemukakan yang berupa bukti-bukti yang kuat untuk mendukung penelitian).

\section{HASIL DAN PEMBAHASAAN}

Berdasarkan temuan penelitian yang dilakukan, terdapat empat gejala depresi yang dialami tokoh utama dalam novel Represi Karya Fakhrisna Amalia.

\section{a. Gejala-gejala Emosional}

Gejala emosional adalah perubahan perasaan atau tingkah laku yang merupakan akibat langsung dari keadaan emosi. Menurut Beck (dalam Lumangga, 2009) sebagai manifestasi penurunan mood, pandangan negatif terhadap diri sendiri, hilangnya kepuasaan,dan hilangnya respon yang menggembirakan.

\section{Data 01}

"Gelombang putus asa datang dalam sekejap dan membuat Anna merasa kesedihan seolah ditimpakhan kepadanya seperti banjir nuh.” (Represi:10)

Berdasarkan data 01 menunjukkan bahwa tokoh Anna mengalami perubahan suasana sedih yang berkepanjangan ketika Anna tau bahwa ibunya membawa ia kepada psikiater. Hal tersebut adanya gejala depresi gejala emosional karena perubahan suasana hati.

\section{Data 02 \\ "Pertemuan dengan ayah dan rasa kecewa yang selalu muncul setiap kali mendapati bahwa ayahnya itu tidak terlalu perhatian kepadanya dan membuatnya capek." (Represi:74)}

Kutipan di atas menunjukkan bahwa Anna mengalami kekecewaan kepada Ayahnya karena ayah selalu mementingkan pekerjaan dibandingkan dengan Anna, dan pertemuan Anna dengan Ayah membuat hati Anna kecewa. Hal tersebut adanya gejala 
depresi emosional perubahaan suasana hati akibat tingkah laku dalam keadaan emosi.

Data 03

"Sejak mulai bersahabat di SMA, Anna memang tidak pernah banyak bicara. Namun Anna tidak pernah sependiam ini. "Anna mau apa?" Seketika Oji bertanya,lalu Anna menjawab" pulang, capek" jawaban itu yang keluar dari mulut Anna. Gadis itu menjawab tanpa menatap lawan bicaranya, jawabanya datar, pendek dan datar secara formalitas .’'(Represi:17)

Kutipan di atas menunjukkan Anna yang menjadi lebih pendiam dan malas untuk mengobrol.hal itu adanya gejala emosional hilangnya respon yang menggembirakan dalam hidup Anna.

\section{Data 04}

"Perjalanan mereka ramai sekali. Anna tidak merasakan keramaian itu sampai dihatinya. Dia hanya menatap kosong keluar jendela, melihat bayangan wajahnya yang kadang-kadang terpantul di kaca jendela lalu merasakan kebencian merayap dalam dirinya "(Represi:19).

Kutipan di atas menunjukkan bahwa Anna merasakanpenurunan mood Anna selalu merasakan kesepian dan selalu merasakan kebencian terhadap dirinya. Hal itu adanya gejala emosional manifestasi penurunan mood.

\section{Data 05}

"Keheningan itu membuat Anna kembali melamun. Gadis itu teringat pada air mata ibunya yang menganak sungai saat dia membuka mata dirumah sakit waktu itu.'(Represi:27)

Kutipan di atas menunjukkan bahwa Anna merasakan keheningan dan meningat apa yang telah terjadi pada dirinya. Hal itu adanya gejala emosional perubahan suasana pada diri Anna.

\section{Data 06}

"Terlalu banyak yang saya rasakan. Kadang saya merasa sedih dan marah. Di sisi lain saya merasa saya harus mengerti bahwa ayah sibuk. Tapi saya sering merasa kecewa ketika ayah bilang gak bisa datang dan ingin dimengerti agar ayah mau meluangkan waktu.”(Represi:33)

Kutipan di atas menunjukkan kekecewaan Anna terhadap ayah karena ayah selalu sibuk pekerjaanya. Hal itu adanya gejala emosional perubahan suasana akibat keadaan emosi.

\section{Data 07}

"Anna mulai menangis saat ingat betapa marahnya dia kepada saka, dan ketika dia ingat bahwa kemarahan itu justru membawanya kepada pilihan yang ia sesali."(Represi:75).

Kutipan di atas menunjukkan kekecewaan Anna kepada saka, karena mengingat kemarahan Anna kepada saka yang tidak membolehkannya Anna jatuh cinta pada saka. Hal ini disebabkan karena adanya gejala emosional perubahan suasana akibat keadaan emosi.

\section{Data 08 \\ "Begitu juga dengan pernyataan bahwa saat ini ia tidak memiliki masa depan.”(Represi:9) \\ Kutipan di atas menunjukkan bahwa Anna berpikir saat ini ia sudah tidak memiliki masa depan yang bisa dicapai. Hal ini disebabkan karena adanya gejala emosional pandangan yang negatif tentang} dirinya.

$\begin{array}{lllr}\text { Data 09 } & & & \\ \text { "Anna } & \text { merasa } & \text { sesak } & \text { mengimpit } \\ \text { dadanya } & \text { dalam } & \text { sekejap. } & \text { Dingin } \\ \text { merayap, rasa } & \text { takut } & \text { kehilangan } \\ \text { menyergap."(Represi: } 107) & \end{array}$

Kutipan di atas menunjukkan bahwa Anna merasakan sesak dalam dadanya karena perilaku Sky. Hal ini disebabkan adanya 
gejala depresi penurunan mood yang dirasakan oleh Anna.

\section{Data 10}

"Dan setelah melarang aku waktu itu, sekarang kamu melakukan hal yang sama lagi? Kamu melarang aku jatuh cinta sama kamu, dan sekarang kamu melarang aku jatuh cinta sama orang lain?Mau kamu apa?aku benci kamu."(Represi hal:133).

Kutipan di atas menunjukkan bahwa Annameluapkan segala emosi nya kepada saka, ketika saka melarang Anna jatuh cinta kepadanya, serta emosi-emosi Anna sendiri yang tidak bisa tersalurkan kepada sky.Hal ini sebabkan adanya gejala emosional perubahan suasana akibat langsung keadaan emosi.

\section{Data 11}

"Suara Aana barusan meninggi dan terdengar ketus. Gadis itu mulai kesal karena pertanyaan ibu beranak pinak. Dia kesal karena ibu menanyaiinya seperti itu. Dia kesel karena ibu selalu ingin tahudan membuat Aana merasa bersalah hanya dengan cara ibu bertanya."(Represi: 143).

Kutipan di atas menunjukkan Aana yang berubah karena emosi kepada ibunya. Hal ini disebabakan karena adanya gejala emosional perubahan suasana karena akibat adanya langsung keadaan emosi.

\section{Data 12}

"Gadis itu semakin kesal. Rasa kesal pada ibu membesar menjadi kekesalan lain yang tidak tahu harus ditunjuk kepada siapa. Aana merasa tidak ada yang bisa memperlakukanya dengan baik dari pada Sky Semua orang membuatnya kesal. Aana kesal sekali sampai rasanya ingin menangis.”( Represi:144).

Kutipan di atas menunjukkan perubahan suasanayang dialami Aana,karena kekesalaan yang dialami nya. Hal ini disebabkan karena adanya gejala emosional perubahan suasan akibat adanya keadaan emosi.

\section{Data 13}

"Hati Aana sudah terasa sakit, bahkan hanya dengan memikirkan kemungkinan itu, akhirnya membuat tidak bisa tidur."(Represi:166)

Kutipan di atas menunjukkan bahwa perubahan suasana hati ketika Aana memikirkan yang menurut Aana tidak mugkin. Hal ini disebabkan gejala emosional perubahan suasana akibat adanya keadaan emosi.

\section{Data 14}

"Aana akhirnya meledak tanpa suara. Dia berhenti menangis begitu saja meski merasakan hatinya berhamburan menjadi serpihan kecil.jiwanya seperti ditarik tiba-tiba. Dan akhirnya Sky berdiri, Aana merasa dirinya jatuh, jauh kelubang yang gelap dan dalam.”(Represi:179)

Kutipan di atas menunjukkan bahwa ada perubahan suasana hati yang dirasakan oleh Aana, merasakan begitu kekecewaan kepada Sky, karena Sky tiba-tiba meninggalkannya. Hal ini disebabkan gejala emosional perubahan suasana akibat adanya keadaan emosi.

\section{Data 15}

"Aana tidak pernah menangis seperti itu. Tangisan kencang, yang disertai jeritan,yang penuh dengan kemarahan dan kesedihan. Rasanya semua yang pernah jadi sepanjang hidupnya, yang berapa diantaranya sudah tidak bisa ia tangisi lagi semuanya menyatu dan meledak bersamaan. ia menangis berteriak,menangis lagi."(Represi:191).

Kutipan di atas menunjukkan bahwa Aana merasaan emosi yang selama ini dia pendam dalam hidupnya. Hal ini disebabkan karena adanya gejala emosional perubahan suasana hati akibat adanya keadaan emosi.

\section{b. Gejala-gejala Kognitif}


Gejala kognitif meliputi penilaian diri sendiri yang rendah, harapan-harapan yang negatif, menyalahkan serta mengkritik diri sendiri, tidak bisa membuat keputusan, dan distory body image.Seperti yang dibuktikan dalam kutipan berikut ini:

\section{Data 01}

"Bagi Anna, psikolog dan psikiater adalah tempat orang-orang sakit jiwa berobat. Sekarang ibunya membawanya kesini, dan Anna tidak tahan untuk tidak berpikir bahwa ibunya menganggap Anna sakit jiwa. Dan Anna berpikir mungkin memang sakit jiwa.'(Represi:9).

Kutipan di atas menunjukkan bahwa Anna menganggap orang-orang yang dibawa ke psikiater adalah orang-orang yang sakit jiwa. Hal ini disebabkan adanya gejala kognitif meyalahkan dan mengkritik diri sendiri.

\section{Data 02}

"Dia hanya menatap kosong ke luar jendela, melihat bayangan wajahnya yang kadang-kadang terpantul di kaca jendela, lalu merasakan kebencian merayap dalam dirinya."(Represi:19).

Kutipan di atas menunjukkan bahwa Aana selalu membenci jika ia melihat wajahnya. Hal ini disebabkan karena adanya gejala kognitif menyalahkan dan mengkritik diri sendiri.

\section{Data 03}

"Aana muak dengan dirinya, Aana benci hidupnya."(Represi:20).

Kutipan di atas menunjukkan bahwa Aana selalu menilai diri nya rendah dan menyalahkan dan mengkritik diri sendiri. Hal ini disebabkan karena adanya gejala kognitif.

\section{Data 04}

"Aana harus menjadi seperti yang diinginkan Ayah dan Ibu. hal ini menjadi sumber masalah diantara Aana dan orangtuanya."(Represi:26).

Kutipan di atas menunjukkan bahwa Aana tidak bisa membuat keputusannya sendiri ia harus selalu mengikuti apa yang orang tuanya inginkan sehingga ini menjadi permasalahan bagi Aana dan orangtuanya. Hal ini disebabkan karena adanya gejala kognitif tidak bisa memutuskan sesuatu sendiri.

\section{Data 05}

"Keheningan itu membuat Aana menyadari hal yang lain lagi, dan hatinya mencelus, saya juga merasa tak berharga."( Represi:36)

Kutipan di atas menunjukkan bahwa Aana selalu merasa dirinya sudah tak berharga. Hal ini disebabkan adanya gejala kognitif penilaian diri yang rendah.

\section{Data 06}

"Suara Aana bergetar seperti menahan tangis. Aana takut jika ia bercerita akan terjadi hal-hal buruk."'( Represi:68).

Kutipan di atas menunjukkan Aana menyerah sebelum melakukannya.hal ini disebabkan karena adanya gejala kognitif harapan-harapan negatif.

\section{Data 07 \\ "Mengabaikan hati kecilnya yang mengingat bahwa Saka sudah ada lebih lama dalam hidupnya dibandingkan dengan Sky, sehingga tidak seharusnyaAana mengiakan permintaan Sky,Aana mengangguk.”(Represi: 90).}

Kutipan di atas menunjukkan bahwa Aana tidak bisa mengikuti apa yang hati kecilnya inginkan, Aana terlalu takut jika ia memilih saka, Sky kan meninggalkan. Hal ini disebabkan karena adanya gejala kognitif tidak bisa memutuskan sesuatu sendiri.

\section{Data 08}

"Terbelah antara keinginan untuk tetap pergi datau menurut pada keinginan 
Sky, Aana kehilangan kata-kata. Aana sudah menunggu bertahun-tahun untuk bisa ikut lomba melukis, dan orang yang paling diaharapkan justru melarang.”(Represi:128).

Kutipan di atas menunjukkan bahwa Sky selalu mengendalikan Aana, dan Aana takut kehilangan Sky sehingga Aana tidak bisa memutuskan segala hal untuk dirinya sendiri. Hal ini disebabkan adanya gejala kognitif tidak bisa memutuskan sesuatu sendiri.

\section{Data 09}

"Karena saya ngga seberharga itu untuk mendapatkan semua hal-hal baik di dunia.”(Represi:156).

Kutipan di atas menunjukkan bahwa Aana menilai dirinya yang rendah sehingga tidak ada hal baik untuknya. Hal ini disebabkan adanya gejala kognitif penilaian diri yang rendah.

\section{Data 10}

"Telah begitu lama Aana menyimpan luka itu. Dari Ayah,ibu, bahkan sahabatnya. Aana beberapa kali ingin bercerita, tapi tidak bisa. Gadis itu selalutakut dengan kemungkinankemungkinan reaksi yang diterima dari lawan bicaranya.Dia takut bercerita justru akan membuatnya semakin terluka."(Represi:183).

Kutipan di atas menunjukkan bahwa Aana begitu banyak kesedihan dalam hidupnya ia selalu takut dengan harapanharapan ketika ia bercerita, jika Aana bercerita siapa tau Aana bisa sedikit lebih lega menghadapi masalahnya.Hal ini disebabkan adanya gejala kognitif harapanharapan negatif.

\section{Data 11}

"Aana selalu ada perasaan tidak nyaman ketika melihat dirinya di cermin.Aana bahkan merasa ajijik denganbentuk tubuhnya ketika remaja.”(Represi:188).
Kutipan di atas menunjukkan bahwa Aana membenci bentuk tubuhnya. Hal ini disebabkan karena adanya gejala kognitif body image ia tidak percaya diri dengan bentuk tubunya sendiri.

\section{c. Gejala-gejala Motivisonal}

Gejala motivisonal berkaitan dengan menurunnya motivasi dan semangat.Menjalani hidup.gejala motivasinal menjurus pada ketergantungan terhadap orang lain dan pada kasus yang parah dapat menyebabkan adanya keinginan bunuhdiri.Seperti yang dibuktikan dalam kutipan berikut ini:

\section{Data 1 \\ "Ibu menemukan Aana tergeletak di lantai kamar dan botol berisi cairan obat nyamuk disampingnya.”(Represi:13).}

Kutipan di atas menunjukkan bahwa keinginan bunuh diri Aana sangat kuat tapi Aana bisa terselamatkan karena ibunya langsung membawanya ke rumah sakit. Hal ini disebabkan karena adanya gejala motivisional adanya keinginan bunuh diri.

\section{Data 2}

"Seketika,Aana membatin.Bagaimana rasanya ditabrak truk."'(Represi:14)

Kutipan di atas menunjukkan keinginin bunuh diri dan mati Aana sangat kuat. Hal ini disebabkan adanya gejala motivisional adanya keinginan bunuh diri.

\section{Data 3}

"Aana berjalan lambat ke arah para sahabatnya.Gadisitu sebenarnya tidak ingin pergi ke kantin. Dia tidak lapar. Dia tidak ingin makan. Dia ingin mati."(Represi:16).

Kutipan di atas menunjukkan bahwa Aana malas untuk beraktivitas yang ia inginkan hanya mati dan mati. Hal ini disebabkan karena adanya gejala motivisional 
tidak semangat menjalani hidup dan ia hanya ingin mati.

\section{Data 4}

"Bagi Aana, bicara berarti menjalankan kehidupan, dan Aana sudah tidak ingin menjalani kehidupannya lagi.”(Represi:22).

Kutipan di atas menunjukkan bahwa sudah tidak ada semangat hidup dalam diri Aana. Hal ini disebablan karena adanya gejal kognitif menurunya semangat hidup.

\section{Data 5}

"Aana juga ingin mati karena tahu tidak akan ada yang mengerti dan ia tidak bisa menghadapinya sendiri."(Represi:34).

Kutipan di atas menunjukkan bahwa sudah tidak ada semangat hidup dalam diri Aana. Hal ini disebabkan karena adanya gejala kognitif menurunya semangat hidup.

\section{d. Gejala-gejala fisik}

Gejala fisik antara lain kehilangan nafsu makan, gangguan tidur, mudah lelah, kehilangan libido, serta kehilangan minat pada orang lain. Seperti yang dibuktikan dalam kutipan berikut ini:

\section{Data 1}

"Nafsu makan Anna memang menurun derastis selama berminggu-minggu, bahkan sebelum percobaan bunuh diri itu terjadi."(Represi:58)

Pada kutipan di atas Tokoh Anna kehilangan nafsu makan, hal ini sesuai dengan pernyataan Beck yang menyebutkan salah satu gejala fisik yaitu hilangnya nafsu makan yang bertanda awal depresi.

\section{Data 2}

"Semakin lama, kenangan-kenangan yang Aana ceritakan pada Nabila, semaki berat dan semakin emosional. Sehingga Aana semakin cepat lelah setiap kali menceritakan kenangan demi kenangan itu.'(Represi:146)

Pada kutipan di atas menjukan Aana mudah lelah dengan dirinya. Hal ini disebabkan karena adanya gejala fisik mudah lelah.

\section{Data 3}

"Mimpi buruk Aana selalu diawali dengan keberadaanya didalam ruanga kecil remang-remang.gadis itu merasa takut, tapi tidak tahu takut terhadap apa atau siapa.ketakutan itu membuat ia menangis dan memeluk diri sendiri dan kedua tangan”(Represi:39.

Kutipan di atas menunjukkan bahwa Aana selalu bermimpi buruk, tapi Aana tidak mengerti dengan pertanda mimpi buruknya, itu yang membuat Aana takut sehingga ia dibawa ke psikiater oleh ibunya.Hal ini disebabkan karena adanya gejala fisik yang dialami oleh Ana.

\section{SIMPULAN}

Berdasarkan hasil penelitian mengenai gejala depresi tokoh utama dalam novel Represi karya Fakhrisna Amalia, dapat disimpulkan bahwa tokoh yang bernama Shira adalah individu rekaan yang mengalami pristiwa atau prilaku yang dilakukan dalam novel Represi, tokoh menunjukkan pada orangnya atau pelaku dari sebuah cerita yang muncul dari kalimatkalimat mendeskripsikannya dari kata-kata yang diletakan di bibirnya, dari seorang pengarang.

Tokoh sangat berkaitan dengan karya sastra karna tokoh merupakan gambaran dari tingkah laku dalam sebuah cerita, yang dilihat dari segi kehidupannya. Sedangkan psikologi sastra ilmu yang mengkaji tentang kejiwaan manusia dengan citra estetik yang dibuat dan dipahami oleh kesadaran imajinatif dalam sebuah karya sastra. Berdasarkan hasil penelitian yang dilakukan dengan nggunakan teori Aaron Beck, terdapat empat gejala depresi yang dialami tokoh utama yaitu gejala emosional (15 data), Kogntif (11 data), Motivisional: (5 data) dan fisik (3 Data). Dalam hal ini, tokoh utama cenderung lebih banyak mengalami gejala emosional, karena tokoh utama cenderung mengalami penurunan mood, dan perubahan perilaku karena dalam keadaan emosi. 


\section{REFERENSI}

Alber, A. (2017). Morfofonemik dalam Pantun Tunjuk Ajar Melayu Karya Tenas Effendy. Konferensi Linguistik Tahunan Atma Jaya 15. https://lib.atmajaya.ac.id/default.aspx?

Alber, A., \& Rahayu, S. (2017). Kohesi Teks Syair dalam Tunjuk Ajar Melayu Karya Tenas Effendi. GERAM (Gerakan Aktif Menulis), 5(1), 58-65. https://doi.org/https://doi.org/10.25299/ger am.2017.vol5(1).421

Amalia, F. (2018). Represi. Jakarta: Gramedia Pustaka Umum.

Diana, F. (2014). Gejala Depresi dalam film Tristan etiseut Tinjauan psikoanalitis. Jurnal Falkutas Ilmu Kebudayaan, Universitas Brawijaya.

Kemenkes. (2018). Kesehatan Dasar (RISKESDAS) Indonesia. akarta: Badan Penelitian dan Pengembangan Kesehatan Desa.

Khotimah, N. (2019). Depresi Tokoh Mu dan Shu Yawang dalam Film Sweet Sixteen Sutradara Jo Jin-Kyu (Kajian Psikologi Sastra). Fakultas Bahasa Dan Seni Univeritas Negeri Surabaya. https://ejournal.unesa.ac.id/index.php/mana darin/article/view/27936

Luh, G. S. H. (2017). Gejala dan Jenis Depresi pada Tokoh Yves dalam Film Saint Laurent: Kajian Psikologi Abnormal. Fakultas Ilmu Budaya Universitas Brawijaya. https://123dok.com/api/v3/get_link/q2691o 2z/data01/2376005

Lumangga, L. N. (2009). Depresi Tinjauan Psikolpgis. Jakarta: Prenada Media Grup.

Minderop, A. (2013). Psikologi Sastra. Jakarta: Yayasan Pustaka Obor Indonesia.

Moleong, J. L. (2016). Metode Peneliitian Kualitatif. Bandung: Remaja Rosdakarya.

Pradana, J. A. (2016). Kamu Bisa Bantu Selamatkan 10.000 Jiwa Setiap Tahun.

Rahmayanti, Y. E., \& Rahmawati, E. (2018). Hubungan Dukungan Keluarga dengan Kejadian Depresi pada Remaja Awal Jurnal Asuhan Ibu \& Anak. Jurnal Asuhan Ibu \& AnakAnak, 3(2), 47-53.

Ratna, N. K. (2010). Teori, Metode, dan Teknik Penelitian Sastra. Denpasar: Pustaka
Pelajar.

Suriadiman, N., \& Anita, F. (2021). Pemerolehan Bahasa Anak Usia 4 Tahun (Studi Kajian Morfologi) di Paud Sahira Kota Pekanbaru Provinsi Riau. GERAM (Gerakan Aktif Menulis), 9(1), 56-64. https://doi.org/https://doi.org/10.25299/ger am.2021.vol9(1).6512

Winarni, W. E. (2018). Teori dan Praktik Penelitian Kuantitatif Kualitatif. Jakarta: Bumi Askara.

Yanti, C. S. (2015). Religiositas dalam Novel Ratu yang bersujud karya Amrizal Mochamad Mahadvi. Humanika. http://ojs.ac.id/index.php/HUMANIKA/arti cle/donwlod/585/pdf 